\title{
LVII. On dilating Caoutchouc bottles by inflation
}

\section{B.M. Forster Esq.}

To cite this article: B.M. Forster Esq. (1822) LVII. On dilating Caoutchouc bottles by inflation , Philosophical Magazine Series 1, 59:288, 263-263, DOI: 10.1080/14786442208652734

To link to this article: http://dx.doi.org/10.1080/14786442208652734

曲 Published online: 29 Jul 2009.

Submit your article to this journal 준

III Article views: 2

Q View related articles $₫$ 


\section{$\left[\begin{array}{ll}263 & ]\end{array}\right.$}

LVII. On dilating Caoutchouc Bottles by Inflation. By B. M. Forstir, Esq.

\section{To Dr. Tilloch.}

SrR, - $\mathbf{T}_{H E}$ great expansibility of the Caoutchouc or Indiarubber is well known: but I am not aware that any endeavours have heretofore been made to inflate the bottles made of that substance, with air, with a view to enlarge their capacity. On Tuesday the 19th instant, I threw some air into a small bottle of it, with a condensing syringe, which caused a small blister (if so I may call it) on the lower part of the bottle; since which, by proceeding in the same way, the bottle was enlarged from about two inches and a half (diameter) to about six and a half. I do not know exactly the dimensions. The mode of the expansion is to me rather surprising: the globe did not expand in an uniform manner, but a blister was formed which increased from what may be called the bottom (if the term bottle is used) towards the neck, where the syringe was connected. I have this evening blown it up without a condensing syringe to very nearly six inches diameter. For some way below the neck the India-rubber retains its usual appearance, not being stretched out like the other part; which part has the look of an animal's bladder, full blown; or a globe of thin horn. I am of opinion that globes of this kind will in many respects be found preferable to bladders for philosophical and other purposes. If the expansion can be continued to a very considerable extent, I am in hopes that air lalloons may be made with these globes. In two trials I have burst the bottles before the expansion was arrived at nearly the degree to what it was in the instance above mentioned.

It has appeared to me remarkable, when (warmed) paper has been excited with a piece of India-rubber, that the rubber showed very little signs of being electric, although the paper was strongly electrified. 'This caoutchouc globe when rubbed on paper (warmed) becomes strongly electric, and produces sparks attended with snappings.

Walthamstow, Essex, March 26, 1822. $\quad$ B. M. Forster, 